ANTIQUITY AND ANACHRONISM IN JAPANESE HISTORY 
<smiles>CCC</smiles> 


\section{JEFFREY P. MASS}

\section{Antiquity and Anachronism in Japanese History}

Stanford University Press

Stanford, California 
Stanford University Press Stanford, California (C) 1992 by the Board of Trustees of the Leland Stanford Junior University

CIP data appear at the end of the book

Publication of this book has been supported by the Japan Fund of Stanford University.

Original printing 1992 Last figure below indicates year of this printing: $\begin{array}{llllllllll}\text { 04 } & \text { 03 } & \text { o2 } & \text { o1 } & \text { oo } & 99 & 98 & 97 & 9^{6} & 95\end{array}$

Stanford University Press publications are distributed exclusively by Stanford University Press within the United States, Canada, Mexico, and Central America; they are distributed exclusively by Cambridge University Press throughout the rest of the world. 
For my students, who have influenced me in more ways than they can imagine 
